\title{
A study of the effectiveness of sewage treatment plants in Delhi region
}

\author{
Sandeep Kumar Gautam • Divya Sharma • \\ Jayant Kumar Tripathi · Saroj Ahirwar · \\ Sudhir Kumar Singh
}

Received: 4 March 2012/Accepted: 26 August 2012/Published online: 16 September 2012

(C) The Author(s) 2012. This article is published with open access at Springerlink.com

\begin{abstract}
This is a conventional kind of monitoring study. The objective of the study was to assess and monitor the physicochemical parameters in wastewater at inlet and outlet of sewage treatment plant (STP) and also to study the effectiveness of the STPs. The average concentration of parameters at inlet sampling site $\mathrm{pH}$, electrical conductivity, total dissolved solids, are 7.16, 2,169 $\mu \mathrm{S} / \mathrm{cm}, 766.06 \mathrm{mg} / \mathrm{l}$, and major ions bicarbonate, nitrate, sulphate, phosphate, chloride, sodium, potassium, magnesium and calcium values $515.88,4.28,82.85,15.17,7.01,23.08,29.34,4.14$ and $84.31 \mathrm{mg} / \mathrm{l}$. While the average concentration of these parameters, after treatment shows following values 7.47, $2,161.43(\mu \mathrm{S} / \mathrm{cm}), 695.81,436.52,1.25,99.22,12.69,6.83$, $23.18,29.07,4.40$ and $82.65 \mathrm{mg} / \mathrm{l}$, respectively. Further, to check the $\mathrm{Na} \%$ and sodium absorption ratio at inlet and outlet which $27.89 \%, 0.67$ and $28.19 \%, 0.68$, respectively, for the suitability of the wastewater. Finally, the agglomerative hierarchical clustering techniques were used to study the similarity in the sewage treatment plants. The result suggests that there is considerable improvement in the wastewater quality after treatment except at the Pappankalan and Coronation Pillar, Timarpur.
\end{abstract}

S. K. Gautam $(\bowtie) \cdot$ D. Sharma · J. K. Tripathi

School of Environmental Science, Jawaharlal Nehru University,

New Delhi 110067, India

e-mail: kgmsandeep@gmail.com

S. Ahirwar

Department of Applied Microbiology and Biotechnology,

Dr. H.S. Gour University Sagar, Madhya Pradesh, India

S. K. Singh

K. Banerjee Centre of Atmospheric and Ocean Studies, KBCAOS, Nehru Science Centre, IIDS, University of Allahabad, Allahabad 211002, India
Keywords Sewage treatment plant · Wastewater . Water quality $\cdot$ Pollution $\cdot$ Monitoring $\cdot$ Delhi

\section{Introduction}

Discharge of untreated sewage water in the water body is a common practice in many countries. This is the common cause for pollution of surface and groundwater because there is a large gap between generation and treatment of domestic wastewater in India. In general, the wastewater discharged from domestic premises like residences, institutions, and commercial establishments is termed as sewage or wastewater. Normally domestic and municipal wastewater are composed of $99.9 \%$ water and remaining $0.1 \%$ suspended, colloidal and dissolved solids, mainly organic in nature because it consists of maximum amount of carbon compounds, viz., human waste, paper, vegetable matter, etc., and it also contributes pathogens which consumes available oxygen from water bodies. Besides this, industrial wastewater gets mixed with municipal waste polluting the water bodies and land which is irrigated by the wastewater.

The wastewater is not used directly for drinking purposes because it contains ions, metals and microorganism which could be harmful to humans if their concentration or numbers exceeds from permissible limit. Therefore, the increasing demand for fresh drinking water and for others purposes such as water for gardening, washing, etc., is met by groundwater, continuously withdrawn from ground and it also poses many environmental and sociological problems in the region. The treated wastewater could act as an alternative to groundwater for some uses.

The treatment of sewage water requires physical, chemical and biological methods. Many previous studies 
have shown that after the treatment of sewage water, sewage sludge forms which still contains much higher amount of organic contaminants, which are present in higher concentrations, are applied to agricultural soils (Singh et al. 2004; Frank Laturnus et al. 2007). Similarly, another study (Foresti et al. 2006) had also reported that the utility of anaerobic processes as the core technology for sustainable domestic wastewater treatment. Anaerobic digesters have been responsible for the removal of large fraction of organic matter (mineralization of waste sludge) in conventional aerobic sewage treatment plants since the early years of domestic sewage treatment (DST). Orhon et al. 1997 have studied the domestic sewage water quality in terms of major polluting parameters. Biomethanation process is very common in domestic and industrial waste treatment in Indian scenario (Tare et al. 1997). Domestic and industrial sewage generated within the National Capital Territory (NCT) of Delhi is the main source of pollution of the river Yamuna during its passage through the NCT. Almost the entire treated and untreated sewage of Delhi which is discharged in river Yamuna contributes $80 \%$ of the river Yamuna's pollutant load.

Despite over 10 years of efforts and expenditure of Rs. 872 crore since 1994 on establishment of sewage treatment infrastructure for treating the domestic and industrial sewage before its release into the river, water quality of the river Yamuna is still very far away from normal river water (Govt. report 2005). Low polycyclic aromatic hydrocarbons are also present in the sewage sludge. These can also be successfully treated by aerobic bioreactors (Trably and Patureau 2006). Sato et al. 2005 have studied the prospect for a self-sustainable sewage treatment system. Monitoring of different sites requires money and manpower; this could be reduced by clustering techniques. The application of hierarchical classification approach is well known for the interpretation of data and provides a valuable tool for reliable and effective monitoring and management (Singh et al. 2009).

Methods of wastewater treatment were first developed in response to the adverse conditions caused by the discharge of wastewater to the environment and the concern for public health. Further, as cities became larger and larger, limited land was available for wastewater treatment and disposal, principally by irrigation and intermittent filtration. Also, as populations grew, the quantity of wastewater generated rose rapidly and the deteriorating quality of this huge amount of wastewater exceeded the self-purification capacity of the streams and river bodies.

Objectives of study: The main objective was to collect wastewater samples from various sewage treatment plant (STP) operating within Delhi region to understand the physicochemical property of wastewater generated as domestic waste. In addition, specific objective was to compare the physicochemical property of wastewater at inlet and outlets of STP to analyze the efficiency of treatment plants for those analyzed parameter and identification of similar sites.

\section{Study area}

Delhi lies in the latitude/longitude $28^{\circ} 38^{\prime} / 77^{\circ} 13^{\prime}$. At present, the total quantity of sewage generated is 2,871 million liters per day (mld), whereas the total capacity of the sewage treatment plants in Delhi is 1,478 mld (see Tables 1, 2 for detailed capacity of different plants and common treatment method used). The remaining $48 \%$ untreated sewage $(1,393$ mld $)$ finds its way into the Yamuna River through the 19 major drains which carry sewage and industrial effluents from the city. As a result, the quality of river water has been deteriorating and the water in the river is at present unfit for drinking (even for animals) and for use in agriculture. The sewerage facilities cover only about $75 \%$ of the population. The sewage system is nonexistent in large parts of the transYamuna area, all the resettlement colonies, and illegal

Table 1 Sewage treatment capacity of different STPs located in Delhi

\begin{tabular}{lllll}
\hline S. no. & $\begin{array}{l}\text { Name of } \\
\text { STP }\end{array}$ & $\begin{array}{l}\text { Capacity } \\
\text { (MGD) as on } \\
31.3 .2001\end{array}$ & $\begin{array}{l}\text { Capacity } \\
\text { (MGD) by } \\
31.3 .2006\end{array}$ & $\begin{array}{l}\text { Actual treatment } \\
\text { in MGD as on } \\
31.3 .2006\end{array}$ \\
\hline 1. & Okhla & 140 & 140 & 119 \\
2. & Keshopur & 72 & 72 & 68.6 \\
3. & Coronation & 46 & 46 & 26.0 \\
& $\quad$ Pillar, & & & \\
& $\quad$ Timarpur & & & \\
4. & Rithala & 40 & 80 & 42.0 \\
5. & Vasant Kunj & 5 & 5 & 4.10 \\
6. & Pappankalan & 20 & 20 & 8.2 \\
7. & Najafgarh & 5 & 5 & 0.2 \\
& Total & 328 & 368 & 268.1 \\
\hline
\end{tabular}

Source: Delhi Jal Board

Table 2 List of technologies with the plants being run on it

\begin{tabular}{lll}
\hline 1. & $\begin{array}{c}\text { Conventional activated sludge } \\
\text { process }\end{array}$ & $\begin{array}{l}\text { a. Rithala } \\
\text { b. Okhla } \\
\\
\end{array}$ \\
& c. Pappankalan \\
& d. Keshopur \\
2. & Extended aeration process & a. Najafgarh \\
& b. Vasant Kunj \\
3. Trickling filters & a. Coronation Pillar, \\
& & Timarpur \\
\hline
\end{tabular}


settlements. The conventional method for estimation of generated wastewater is derived at $80 \%$ of the water supplied. However, this may not be realistic in the areas like Delhi (see Fig. 1) where large quantity of ground water is simultaneously extracted and utilized. Efforts have been made to find the cumulative pollution load addition to river Yamuna (23 km stretch from Wazirabad Barrage to Okhla Barrage) at various points by the major drains carrying wastewater from NCT of Delhi; making these open sewers in turn causing foul smell, bad quality and groundwater contamination all along the drain and ultimately polluting disposal sink to river Yamuna.

\section{Materials and methods}

A total of 14 samples were collected for the study in the year 2007-2008. These 14 samples were representing seven inlets and seven outlets of the same STP. The $\mathrm{pH}$ and conductivity were measured from unfiltered water samples. The $\mathrm{pH}$ was measured by Rachho (model no. 123) $\mathrm{pH}$ Meter. Systronics conductivity meter was used for the measurement of conductivity and TDS. The bicarbonate content was determined following the potentiometric titration method (American Public Health Association (APHA) 1995). Nitrate was estimated by brucine method. Nitrate and brucine react to produce a yellow color, the intensity of which can be measured at $410 \mathrm{~nm}$. The method is suitable for the samples with a very wide range of salinity. Sulphate was analyzed by turbidimetric method. Suspended matter and original color of the sample may interfere with the sulphate determination. Suspended matter can be removed by filtration. Presence of silica in excess of $500 \mathrm{mg} / \mathrm{l}$ and large quantity of organic matter may affect the satisfactory precipitation of barium sulphate. The ascorbic acid method (APHA 1995) determined phosphate. Optical density was measured at $650 \mathrm{~nm}$ using Cecil Spectrophotometer (model no. 594). Chloride was determined by spectrophotometer. Cations such as $\mathrm{Na}, \mathrm{K}, \mathrm{Ca}$ and $\mathrm{Mg}$ were analyzed using atomic absorption spectrophotometer, Shimadzu-AA-6800. Excessive sodium content in water renders it unsuitable for soils containing exchangeable calcium and magnesium ions. The exchange capacity of water is expressed in sodium absorption ratio (SAR) by Eq. 1 and sodium percentage was calculated by using Eq. 2

$$
\begin{aligned}
\mathrm{SAR} & =\frac{\mathrm{Na}}{[(\mathrm{Ca}+\mathrm{Mg}) / 2]^{0.5}} \\
\mathrm{Na} \% & =\frac{\mathrm{Na}^{+}}{\left(\mathrm{Ca}^{+2}+\mathrm{Mg}^{+}+\mathrm{Na}^{+}+\mathrm{K}^{+}\right)} \times 100
\end{aligned}
$$

\section{Results and discussions}

Wastewater samples were collected at inlet and outlet and analyzed for various chemical parameters and results are

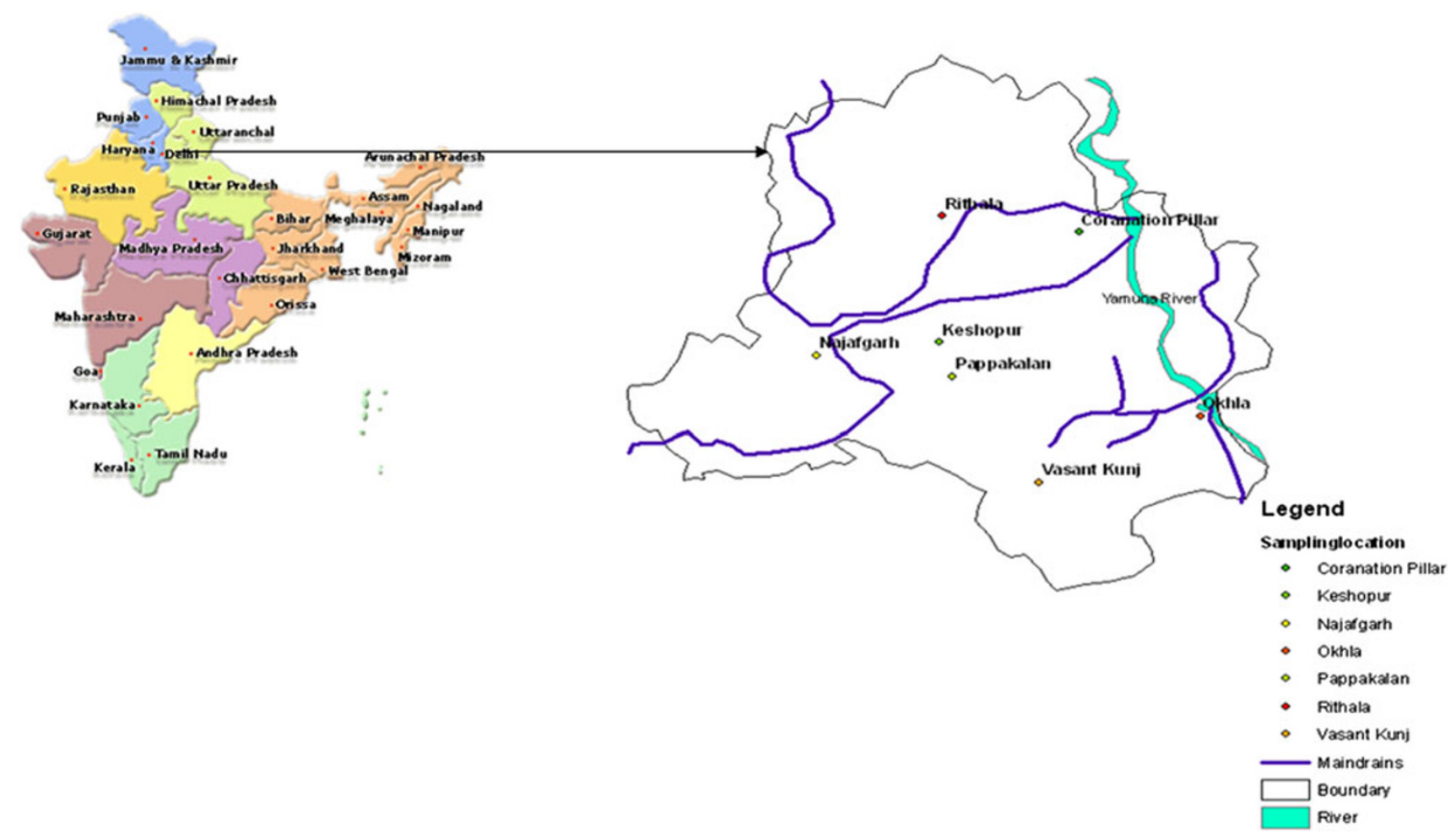

Fig. 1 Study area at which different sewage treatment plants (STPs) are located in Delhi Region

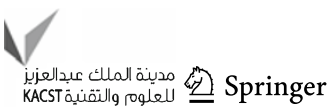


given in (Table 3). The $\mathrm{pH}$ of the wastewater was slightly acidic to alkaline and it ranges from 6.4 to 7.3 before treatment and after treatment its values varies from 7.0 to 7.9 indicates its alkaline nature. The EC value indicate amount of dissolve constituents present in water and used in determining the suitability of water for irrigation (Paliwal and Yadav 1976). The EC of wastewater samples ranges from 1,470 to $4,210 \mu \mathrm{S} / \mathrm{cm}$ at inlet while the average of $2,169 \mu \mathrm{S} / \mathrm{cm}$ and at outlet their value varies from 1,420 to $3,820 \mu \mathrm{S} / \mathrm{cm}$ with an average $2,161 \mu \mathrm{S} / \mathrm{cm}$. The high EC value is attributed to the high salinity and high mineral content. It also corresponds to the highest concentrations of dominant ions which are the result of ion exchange and solubilisation in the water. It shows strong positive correlation with $\mathrm{TDS}, \mathrm{HCO}_{3}{ }^{-}$, and $\mathrm{Ca}^{2+}$ in inlet as well as outlet (Tables 4, 5). Bicarbonate is the major anion present in the fresh water body. The source of bicarbonate is atmospheric $\mathrm{CO}_{2}$, which dissolves in water to form carbonic acid. Reaction of carbonic acid with limestone containing mineral like albite (Garrels and Christ 1965), from partial or complete decomposition of organic matter (Berner 1971) give rise to bicarbonate ion concentration in water body. The bicarbonate concentration of wastewater ranges from 199.26 to $696.33 \mathrm{mg} / \mathrm{l}$ with an average of $515.88 \mathrm{mg} / \mathrm{l}$ in before treatment and after treatment bicarbonate value varies from 316.22 to $550.13 \mathrm{mg} / \mathrm{l}$ with an average $436.52 \mathrm{mg} / \mathrm{l}$. Bicarbonate is having strong positive correlation with $\mathrm{Ca}^{2+}$ and $\mathrm{K}^{+}$in inlet and with $\mathrm{Ca}^{2+}$ and $\mathrm{SO}_{4}{ }^{2-}$ at outlet (Tables 4,5 ). The source of nitrate in wastewater is domestic sewage, runoff from the agriculture field, leachates from the landfill sites. The concentration of nitrate in inlet and outlet wastewater samples varies from 2.28 to $5.08 \mathrm{mg} / \mathrm{l}$ with an average of $4.28 \mathrm{mg} / \mathrm{l}, 0.09$ to $5.67 \mathrm{mg} / \mathrm{l}$ (average $1.25 \mathrm{mg} / \mathrm{l}$ ), respectively. The source of sulphate in water is the solvent action of gypsum, pyrites, galena, chalcopyrite, sphalerite, anhydrite and it is also

Table 3 Inlet correlation matrix the bold values shows significant positive and negative co relation among the variables

\begin{tabular}{|c|c|c|c|c|c|c|c|c|c|c|c|c|}
\hline & $\mathrm{pH}$ & $\mathrm{EC}$ & TDS & $\mathrm{PO}_{4}{ }^{3-}$ & $\mathrm{Cl}^{-}$ & $\mathrm{HCO}_{3}{ }^{-}$ & $\mathrm{SO}_{4}{ }^{2-}$ & $\mathrm{NO}_{3}^{-}$ & $\mathrm{Ca}^{2+}$ & $\mathrm{Mg}^{2+}$ & $\mathrm{Na}^{+}$ & $\mathrm{K}^{+}$ \\
\hline $\mathrm{pH}$ & 1 & & & & & & & & & & & \\
\hline $\mathrm{EC}$ & 0.26 & 1.00 & & & & & & & & & & \\
\hline TDS & 0.74 & 0.63 & 1.00 & & & & & & & & & \\
\hline $\mathrm{PO}_{4}{ }^{3-}$ & -0.26 & -0.18 & 0.06 & 1.00 & & & & & & & & \\
\hline $\mathrm{Cl}^{-}$ & 0.35 & 0.35 & 0.64 & 0.46 & 1.00 & & & & & & & \\
\hline $\mathrm{HCO}_{3}{ }^{-}$ & 0.75 & 0.64 & 1.00 & 0.05 & 0.61 & 1.00 & & & & & & \\
\hline $\mathrm{SO}_{4}{ }^{2-}$ & 0.35 & 0.19 & 0.49 & -0.17 & 0.43 & 0.41 & 1.00 & & & & & \\
\hline $\mathrm{NO}_{3}{ }^{-}$ & -0.44 & 0.04 & -0.32 & -0.39 & -0.63 & -0.28 & -0.51 & 1.00 & & & & \\
\hline $\mathrm{Ca}^{2+}$ & 0.61 & 0.85 & 0.92 & -0.02 & 0.60 & 0.92 & 0.47 & -0.32 & 1.00 & & & \\
\hline $\mathrm{Mg}^{2+}$ & 0.41 & -0.57 & 0.10 & -0.17 & -0.27 & 0.08 & 0.34 & -0.12 & -0.19 & 1.00 & & \\
\hline $\mathrm{Na}^{+}$ & 0.46 & -0.21 & 0.41 & -0.18 & -0.02 & 0.36 & 0.68 & -0.18 & 0.18 & 0.88 & 1.00 & \\
\hline $\mathrm{K}^{+}$ & 0.41 & 0.15 & 0.69 & 0.11 & 0.58 & 0.68 & 0.38 & 0.00 & 0.44 & 0.27 & 0.48 & 1.00 \\
\hline
\end{tabular}

Table 4 Outlet correlation matrix the bold values shows significant positive and negative co relation among the variables

\begin{tabular}{|c|c|c|c|c|c|c|c|c|c|c|c|c|}
\hline & $\mathrm{pH}$ & EC & TDS & $\mathrm{PO}_{4}{ }^{3-}$ & $\mathrm{Cl}^{-}$ & $\mathrm{HCO}_{3}^{-}$ & $\mathrm{SO}_{4}{ }^{2-}$ & $\mathrm{NO}_{3}{ }^{-}$ & $\mathrm{Ca}^{2+}$ & $\mathrm{Mg}^{2+}$ & $\mathrm{Na}^{+}$ & $\mathrm{K}^{+}$ \\
\hline $\mathrm{pH}$ & 1.00 & & & & & & & & & & & \\
\hline $\mathrm{EC}$ & -0.30 & 1.00 & & & & & & & & & & \\
\hline TDS & -0.09 & 0.58 & 1.00 & & & & & & & & & \\
\hline $\mathrm{PO}_{4}{ }^{3-}$ & 0.08 & 0.15 & -0.45 & 1.00 & & & & & & & & \\
\hline $\mathrm{Cl}^{-}$ & -0.58 & 0.49 & 0.44 & 0.25 & 1.00 & & & & & & & \\
\hline $\mathrm{HCO}_{3}{ }^{-}$ & -0.13 & 0.65 & 0.99 & -0.47 & 0.40 & 1.00 & & & & & & \\
\hline $\mathrm{SO}_{4}{ }^{2-}$ & 0.14 & -0.16 & 0.70 & -0.60 & 0.12 & 0.62 & 1.00 & & & & & \\
\hline $\mathrm{NO}_{3}{ }^{-}$ & -0.12 & 0.89 & 0.38 & 0.16 & 0.28 & 0.45 & -0.32 & 1.00 & & & & \\
\hline $\mathrm{Ca}^{2+}$ & -0.42 & 0.96 & 0.68 & -0.02 & 0.60 & 0.74 & -0.03 & 0.81 & 1.00 & & & \\
\hline $\mathrm{Mg}^{2+}$ & 0.21 & -0.20 & 0.10 & 0.23 & 0.40 & -0.02 & 0.34 & -0.05 & -0.19 & 1.00 & & \\
\hline $\mathrm{Na}^{+}$ & 0.43 & -0.52 & -0.49 & 0.15 & -0.76 & -0.52 & -0.07 & -0.37 & -0.70 & -0.06 & 1.00 & \\
\hline $\mathrm{K}^{+}$ & 0.08 & 0.11 & -0.18 & 0.47 & 0.37 & -0.22 & -0.30 & 0.41 & 0.05 & 0.74 & -0.19 & 1.00 \\
\hline
\end{tabular}




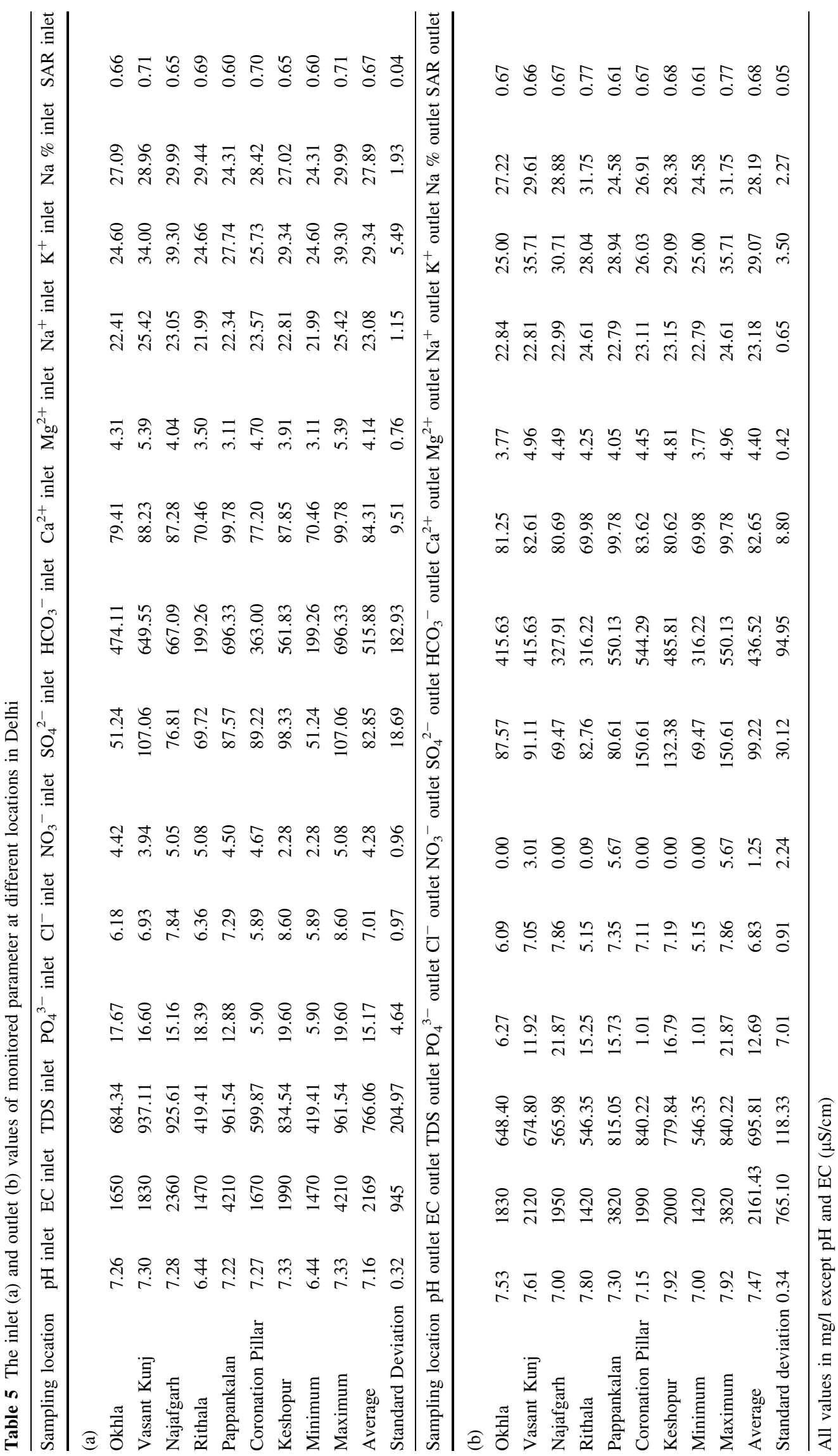




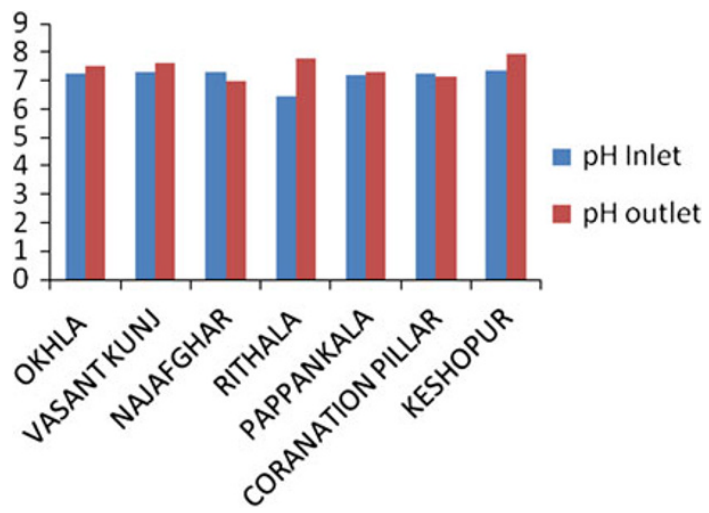

Fig. 2 The $\mathrm{pH}$ inlet and outlet values. $\mathrm{pH}$ values shows slightly increase at all locations except Najafgarh and Coronation Pillar after treatment

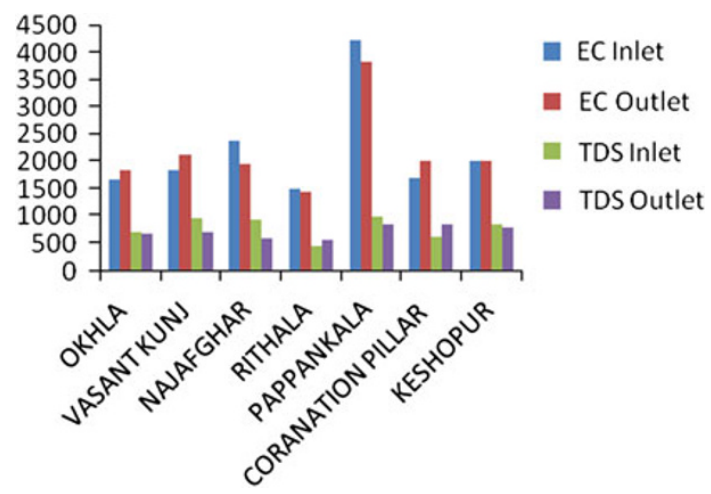

Fig. 3 The EC and TDS inlet and outlet values. EC shows increased value after treatment at Okhla, Vasant Kunj and Coronation Pillar. Similarly TDS increased at Rithala, Coronation Pillar

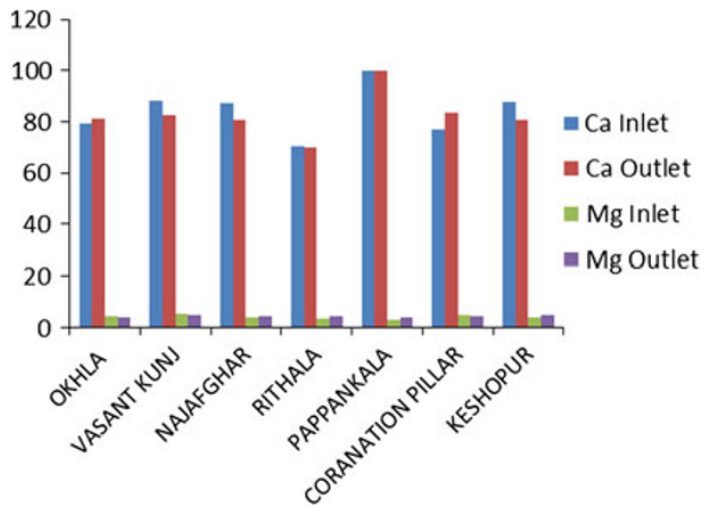

Fig. 4 The $\mathrm{Ca}^{2+}$ and $\mathrm{Mg}^{2+}$ inlet and outlet values, $\mathrm{Ca}^{2+}$ shows higher concentration at Okhla and Coronation Pillar and $\mathrm{Mg}$ shows slight change at Rithala, Pappankalan and Keshopur after treatment

present as final oxidation products of disulphides, sulphite and thiosulphates. The value of sulphate in inlet value ranges from 51.24 to $107.06 \mathrm{mg} / \mathrm{l}$ with an average of $82.85 \mathrm{mg} / \mathrm{l}$ and after treatment its concentration varies from 69.47 to $150.61 \mathrm{mg} / \mathrm{l}$ with an average of $99.22 \mathrm{mg} / \mathrm{l}$.

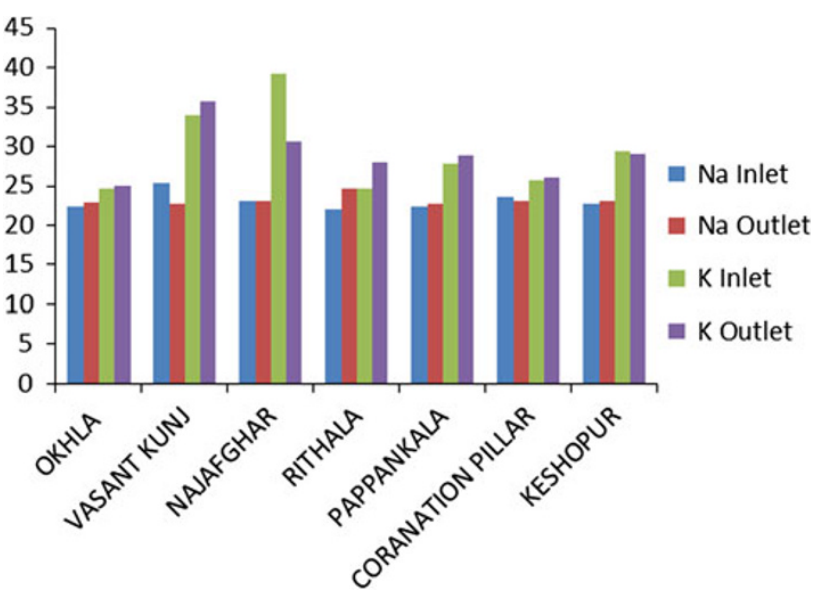

Fig. $5 \mathrm{The}^{+}{ }^{+}$and $\mathrm{K}^{+}$inlet and outlet values, $\mathrm{Na}^{+}$shows slight increase at Okhla and Keshopur and increase at Rithala and $\mathrm{K}^{+}$ increases at Okhla, Vasant Kunj, Rithala and Pappankalan after treatment

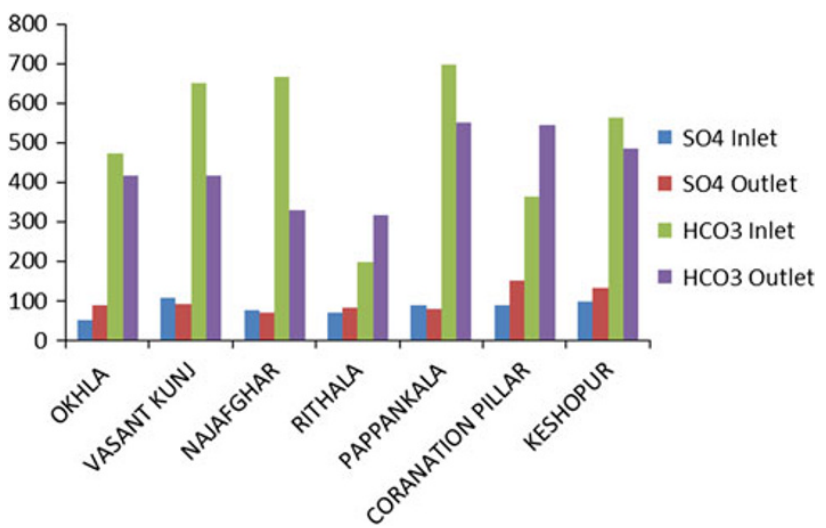

Fig. 6 The $\mathrm{SO}_{4}{ }^{2-}$ and $\mathrm{HCO}_{3}{ }^{-}$inlet and outlet values. Sulphate after treatment shows increased values at Okhla, Rithala, Coronation Pillar and Keshopur and similarly bicarbonate increased at Rithala and Coronation Pillar after treatment

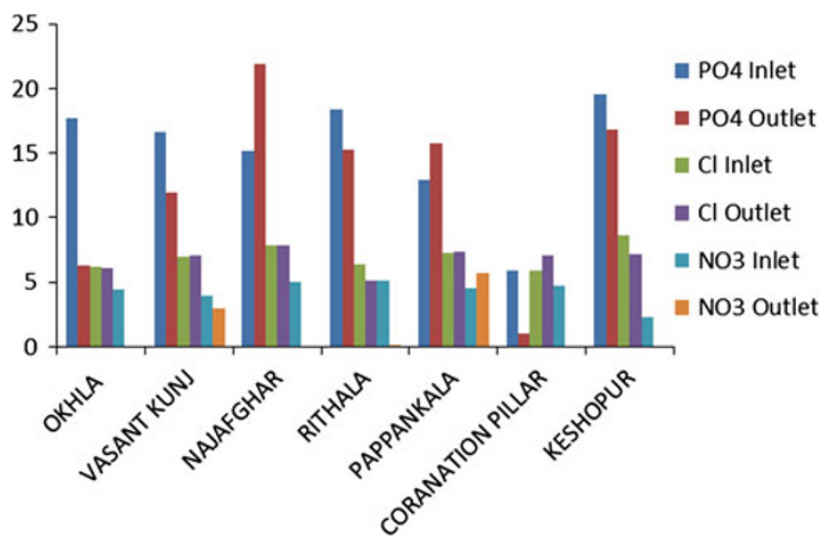

Fig. 7 The $\mathrm{PO}_{4}{ }^{3-}, \mathrm{Cl}^{-}$and $\mathrm{NO}_{3}{ }^{-}$inlet and outlet values. Phosphate and chloride shows higher value at Vasant Kunj, Najafgarh and Pappankalan, and nitrate shows higher concentration at Pappankalan after treatment 


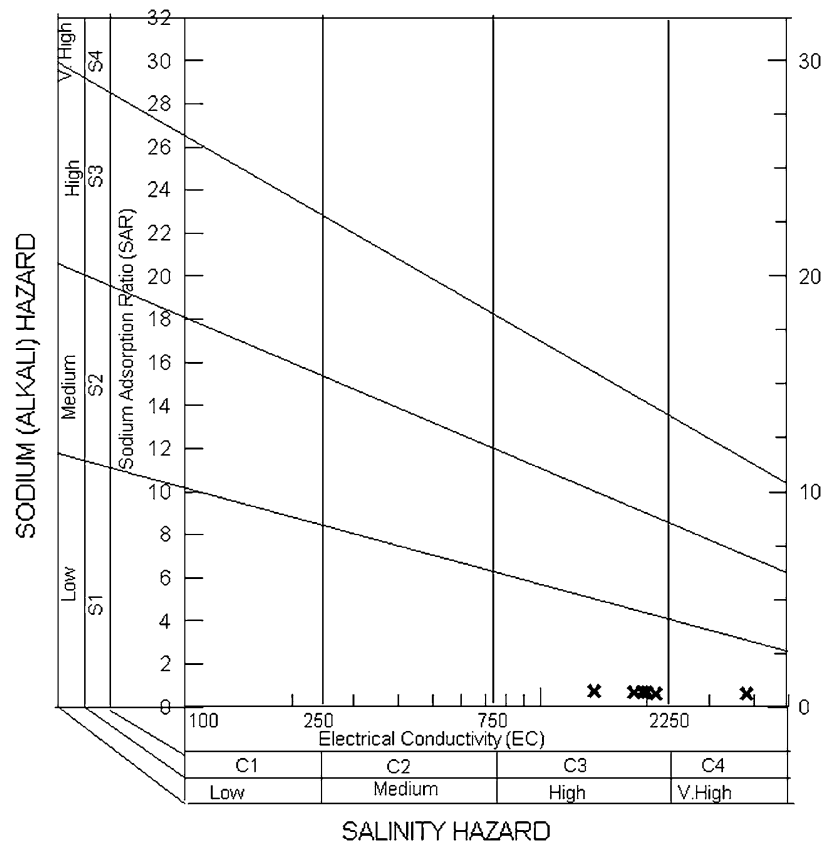

Fig. 8 USSL salinity diagram of wastewater after treatment for irrigation purposes (Richards 1954)

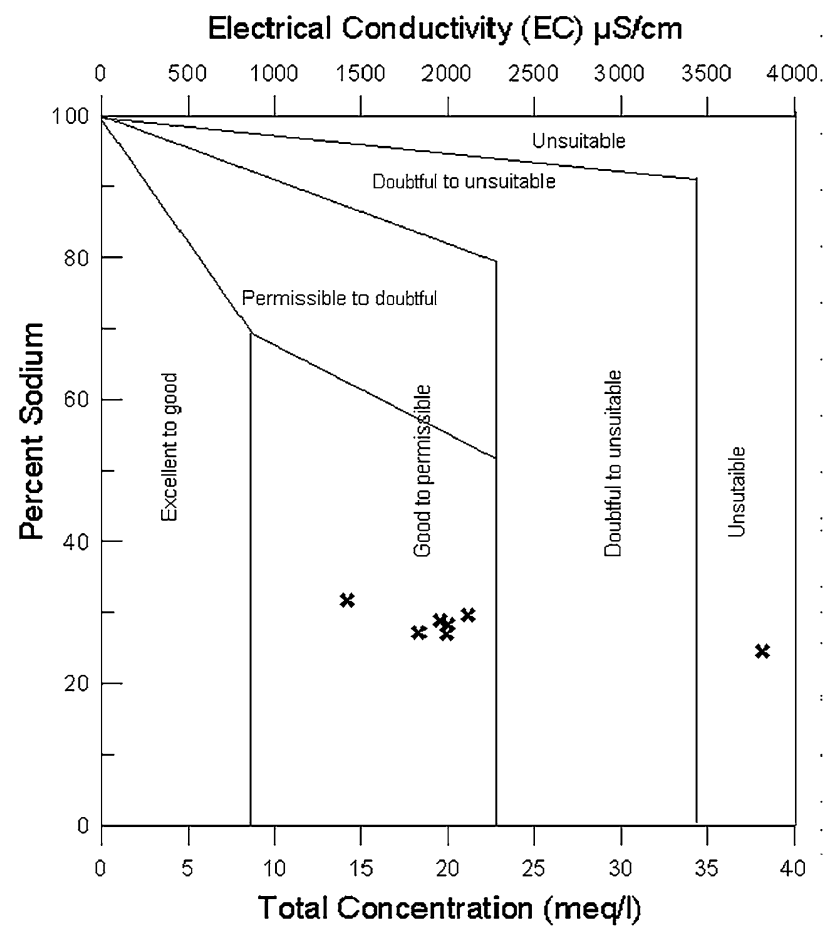

Fig. $9 \mathrm{Na} \%$ versus EC in wastewater after treatment (Wilcox 1955). One sample falls in the doubtful category

The source of $\mathrm{Na}^{+}$in water is weathering of plagioclase, pyroxene and hornblende; evaporate minerals and atmospheric precipitation ( $2 \mathrm{mg} / \mathrm{l}$ ) (Davis and De Wiest 1967). The concentration of $\mathrm{Na}^{+}$in water samples varies from
21.99 to $25.42 \mathrm{mg} / \mathrm{l}$ with an average of $23.08 \mathrm{mg} / \mathrm{l}$ in before treatment and after treatment its concentration varies from 22.79 to $24.6 \mathrm{mg} / \mathrm{l}$ (average $23.18 \mathrm{mg} / \mathrm{l}$ ). Na ${ }^{+}$is showing a strong correlation with $\mathrm{Mg}^{2+}$ at inlet. Sodium is showing higher values because it behaves like conservative element, i.e., it is not used up in biological process or clay mineral formation (Subramanian and Saxena 1983).

The source of $\mathrm{K}^{+}$is weathering of orthoclase, microcline, biotite, K-feldspar, etc., and rainwater $(0.1 \mathrm{mg} / \mathrm{l})$ (Davis and De Wiest 1967). The concentration of $\mathrm{K}^{+}$in water samples varies from 24.60 to $39.30 \mathrm{mg} / \mathrm{l}$ with an average value of $29.34 \mathrm{mg} / \mathrm{l}$ in inlet and outlet its concentration varies from 25.00 to $35.71 \mathrm{mg} / \mathrm{l}$ with an average $29.07 \mathrm{mg} / \mathrm{l}$. The main sources of $\mathrm{Ca}^{2+}$ and $\mathrm{Mg}^{2+}$ in water are calcite, dolomite, magnesite, anhydrite, gypsum, feldspar, pyroxene, amphiboles, etc. The concentration of $\mathrm{Ca}^{2+}$ in inlet water sample varies from 70.46 to $99.78 \mathrm{mg} / \mathrm{l}$ with an average value of $84.31 \mathrm{mg} / \mathrm{l}$ and outlet its values varies from 69.98 to $99.78 \mathrm{mg} / \mathrm{l}$ (average $82.65 \mathrm{mg} / \mathrm{l}$ ). The concentration of $\mathrm{Mg}^{2+}$ in water samples is varies from 3.11 to $5.39 \mathrm{mg} / \mathrm{l}$ with an average value of $4.14 \mathrm{mg} / \mathrm{l}$ in inlet and after treatment concentration of $\mathrm{Mg}^{2+}$ varies from 3.77 to $4.96 \mathrm{mg} / \mathrm{l}$ (average $4.40 \mathrm{mg} / \mathrm{l}$ ) (Figs. 2, 3, 4, 5, 6, 7)

\section{Suitability for irrigation uses}

The treated wastewater is not used for the irrigation purpose because it contains high sodium content, which may be harmful for most soils and requires special water and soil management practices. Water with high amount of bicarbonates and relatively low in calcium is also known to be hazardous for irrigation (Richards 1954) and higher EC in water also creates an adverse effect on saline soil; whereas salt content in irrigation water causes an increase in soil solution osmotic pressure (Thorne and Peterson 1954). EC and sodium concentration are used in classifying irrigation water. The total concentration of soluble salts in irrigation water can be expressed for the purpose of classification of irrigation water as low $(\mathrm{EC}=<250 \mu \mathrm{S} / \mathrm{cm})$, medium $(250-750 \mu \mathrm{S} / \mathrm{cm})$, high $(750-2,250 \mu \mathrm{S} / \mathrm{cm})$ and very high $(2,250-5,000 \mu \mathrm{S} / \mathrm{cm})$ salinity zone (Richards 1954).

The calculated value of SAR in the wastewater after treatment ranges from 0.61 to 0.77 with average value 0.68 while before treatment $0.60-0.71$ with average 0.67 . The plot of data was performed on the US salinity diagram (Fig. 8). In this diagram the EC is taken as salinity hazard and SAR as alkalinity hazard, which shows that most of the wastewater samples fall in the category $\mathrm{C} 3 \mathrm{~S} 1$ and one in C4S1. Indicating low to medium salinity and low sodium water, this can be used for irrigation in most soil and crops with little danger of development of exchangeable sodium, and salinity. 
Fig. 10 Dendrogram (HCA) shows prominent clusters based on after-treatment samples which further help in identifying of similar types of sites
Dendrogram using Ward Method

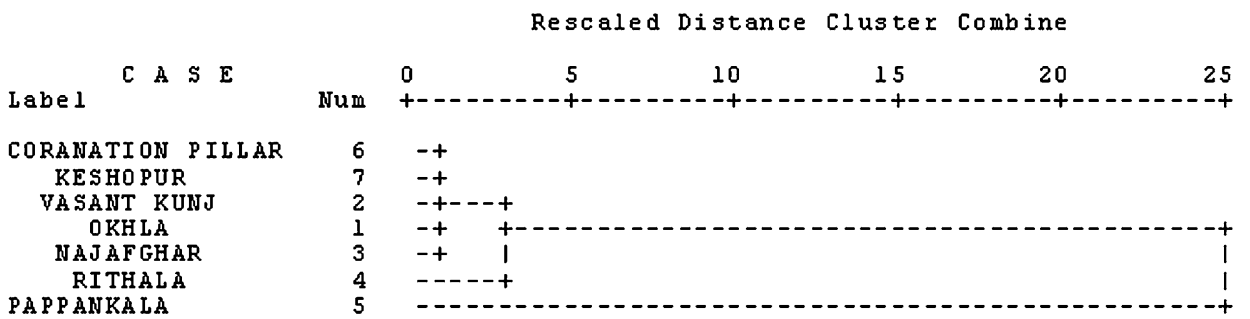

\section{Sodium percentage (Na \%)}

Sodium concentration is important in classifying irrigation water because it reacts with soil to reduce its permeability. Excess sodium in water produces undesirable effects of changing soil properties and reducing soil permeability (Kelley 1951). The Na \% is calculated using the formula given below, where all the concentrations in meq/l. The Wilcox (1955) diagram is relating sodium percentage and electrical conductivity (Fig. 9). The sodium percentage in the inlet wastewater ranges from 24.31 to $29.99 \%$ with average $27.89 \%$ and after treatment 24.58 to $31.75 \%$ with average $28.19 \%$. As per the Bureau of Indian Standard (BIS), maximum sodium of $60 \%$ is recommended for irrigation water. After treatment most of the samples on the Wilcox diagram fall in the categories of good to permissible region, but in Pappankalan region sample fall in the unsuitable category.

\section{Cluster analysis}

Cluster analysis approach is subjective in nature. To investigate the results, further CA was performed to check the similarity between the different STP with the help of outlet parameter. The cluster-rendered dendrogram map was drawn using single linkage Ward's method. Following clusters (see Fig. 10 for details) were formed on the basis of physicochemical parameters which link similar STP site, viz., cluster $1(3,1,2,7$ and 6) cluster 2 (2 and 4) and cluster 3 (2, 4 and 5). This clustering will help in identifying the similar sites, which will further help in long-term monitoring.

\section{Conclusion}

The increasing demand for water supply can be met with the treated sewage water. In this paper, the sample's $\mathrm{pH}$ value after treatment lies in alkaline range. EC is showing higher values $(\max 4,210 \mu \mathrm{S} / \mathrm{cm})$ in Pappankalan inlet. The dominant anion in the water sample is $\mathrm{HCO}_{3}{ }^{-}$ followed by $\mathrm{SO}_{4}{ }^{2-}, \mathrm{PO}_{4}{ }^{3-}, \mathrm{Cl}^{-}$, and $\mathrm{NO}_{3}{ }^{-}$and dominant cation is $\mathrm{Ca}^{2+}$ is followed by $\mathrm{K}^{+}, \mathrm{Na}^{+}$, and $\mathrm{Mg}^{2+}$. In
Rithala, SPT outlet concentration of $\mathrm{HCO}_{3}{ }^{-}$is greater than the inlet concentration because of use of some chemicals during the treatment processes. $\mathrm{Na}^{+}$concentration is higher at outlet as compared to inlet at Rithala and Keshopur STP. Similarly, concentration of $\mathrm{K}^{+}$at Rithala is also more at outlet as compared to the inlet. One of the major problems with these wastewater treatment methods is that none of the available technologies has a direct economic return. The available technologies are unaffordable due to high capital and maintenance costs. The efficiency of STP is not good. In order to improve the efficiencies of the STPs, the treatment systems must be properly operated and maintained, sources of raw sewage identified, and existing facilities upgraded. Long-term monitoring strategy is required to study effectiveness of the STP in depth.

Acknowledgments The author (Sandeep Kumar Gautam) thanks CSIR for providing financial support to carry out the research work. The author also acknowledges the technical and administrative staff of his school for being always attentive and helpful during analysis.

Open Access This article is distributed under the terms of the Creative Commons Attribution License which permits any use, distribution, and reproduction in any medium, provided the original author(s) and the source are credited.

\section{References}

American Public Health Association (APHA) (1995) Standard methods for the examination of water and wastewater, 19th edn. American Public Health Association, Washington DC

Berner RA (1971) Chemical Sedimentology. McGraw Hill Publication, New York

Davis SN, De Wiest RJM (1967) Hydrogeology. Wiley, Inc., New York

Foresti E, Zaiat M, Vallero M (2006) Anaerobic processes as the core technology for sustainable domestic wastewater treatment: consolidated applications, new trends, perspectives, and challenges. Rev Env Sci Bio Technol 5:3-19

Garrels RM, Christ CL (1965) Solutions, minerals and equilibria. Harper and Row, New York

Kelley KR (1951) Alkali soils- their formation properties and reclamation. Reinhold Publ. Corp, New York

Laturnus F, Arnold KV, Gron C (2007) Organic contaminants from sewage sludge applied to agricultural soils. Env Sci Pollut Res 14(1):53-60 
Orhon D, Ate E, Sozen S, Cokgor EU (1997) Characterization and COD fractionation of domestic wastewaters. Environ Pollut 95(2):191-204

Paliwal KV, Yadav BR (1976) Irrigation water quality and crop management in Delhi. Geol Survey INd Misc Publ 14:130-139

Richards LA (1954) Diagnosis and improvement of saline and alkali soils. US Department of Agriculture Handbook 60

Sato N, Okubo T, Onodera T, Ohashi A, Harada H (2005) Prospects for a self-sustainable sewage treatment system: A case study on full-scale UASB system in India's Yamuna River Basin. Environ Mange. doi:10.1016/j.jenvman.2005.08.025

Singh KP, Mohan D, Sinha S, Dalwani R (2004) Impact assessment of treated/untreated wastewater toxicants discharged by sewage treatment plants on health, agricultural, and environmental quality in wastewater disposal area. Chemosphere 55:227-255

Singh SK, Singh CK, Kumar KS, Gupta R, Mukherjee S (2009) Spatial-temporal monitoring of groundwater using multivariate statistical techniques in Bareilly district of Uttar Pradesh, India.
J Hydrol Hydromech 57(1):45-54. doi:10.2478/V10098-0090005-1

Subramanian V, Saxena K (1983) Hydrogeology of ground water in Delhi region of India, Relation of water quality and quantity. In: Proceedings of the Hamberg symposium IAHS publication no. 146

Tare V, Ahammed M, Jawed M (1997) Biomethanation in domestic and industrial waste treatment-an Indian scenario. In: Proceedings of the eighth international conference on Anaerobic Digestion, vol 2. Japan, pp 255-262

Thorne DK, Peterson HB (1954) Irrigated soils. Constable and Company, London

Trably E, Patureau D (2006) Successful treatment of low PAHcontaminated sewage sludge in aerobic bioreactors. Environ Sci Pollut Res 13(3):170-176

Wilcox LV (1955) Classification and use of irrigation waters, USDA Circular No. 969, 19 